\title{
RELIABILITY-BASED ANALYSIS OF ALUMINIUM LAMINATED SOLID TIMBER COLUMNS USING SELECTED NIGERIAN TIMBER SPECIES
}

\author{
S. N. Mangut ${ }^{1, *}$, Idris Abubakar ${ }^{2}$ and A. Ocholi ${ }^{3}$ \\ 1, Department of Civil Engineering TeChnology, Nasarawa State Polytechnic, Lafia, NaSarawa State, Nigeria \\ 2,3, Civil Engineering Department, Ahmadu Bello University, Zaria Kaduna State, NIGERIA \\ E-mail addresses: ${ }^{1}$ mangutsamuel@gmail.com, ${ }^{2}$ idrcivil1@gmail.com, ${ }^{3}$ amanaocholi@yahoo.com
}

\begin{abstract}
This paper presents the results of safety assessment of timber columns laminated with aluminium using the First Order Reliability Methods. Three failure modes were considered in the studies: bending failure, buckling failure, and flexural buckling failure modes. The results show that the column is safer for compression failure mode which has safety index values of 4.3 and 9.68 for imposed load and dead-to-live load parameters respectively without laminates, and progressive safety indices of up to 12.4 and 20.87 respectively for columns with laminates of $20 \mathrm{~mm}$ thickness. The study showed that the most critical failure mode for the column is the flexural buckling mode. It is therefore deduced that from the results of the critical failure mode, laminate thickness of $10 \mathrm{~mm}$ should be used to withstand any variation in load ratios of $0.6,0.8$ and 1.0 and a maximum imposed load of $15 \mathrm{kN}$ be used to ensure a safe column design.
\end{abstract}

Keywords: reliability, critical failure mode, stochastic, composite, limit state

\section{INTRODUCTION}

The analysis and design of timber structures are done bearing in mind the fact that timber is of variable strengths both within same species and for various species. These variations are accounted for by the natural growth of their parent trees whereby there is little or nothing that can be done to control the final strength properties (physical and mechanical) of the resulting structural timber. The use of timber for structural purposes cuts on the emission of greenhouse gases which are products of the manufacture of conventional building materials. The good aspect of timber is that it has a very high strength-to-weight ratio, it is capable of transferring both tension and compression forces, and is naturally suitable as a flexural member [1].

Composite engineering seeks ways to overcome the limitations present in both constituent materials by using the more pronounced strength properties on one material to cover up for the defects or limitations found in the other material. Lamination is a technique of external reinforcement of structural components. The limitation in sectional properties of available timber is also a factor for the use of Aluminium laminates.

Aluminium is a lightweight and durable metal. Aluminium has two main advantages when compared with other metals for structural use. Firstly, it has a low density, about one third that of iron and copper. Secondly, although it reacts rapidly with the oxygen in air, it forms a thin tough and impervious oxide layer which resists further oxidation [2]. This makes aluminium desirable in structures especially in marine areas. The main mechanical properties of Aluminium are: elastic limit $\left(f_{0.2}\right)$ or yield stress $\left(f_{y}\right)$, ultimate strength ( $\mathrm{ft}$ ), Young's modulus (E): $70,000 \mathrm{~N} / \mathrm{mm}^{2}$, ultimate elongation $(\varepsilon)$, specific weight $(\mathrm{Y})$ : $27,000 \mathrm{~N} / \mathrm{m}^{3}$, thermal elongation coefficient (a): $23 \times 10^{-6}$ per ${ }^{\circ} \mathrm{C}$ and Poisson Ratio (v): $0.3[3,4]$.

Reliability of structural systems can be defined as the probability that a structure under consideration has a proper performance throughout its lifetime [5]. The aim of structural reliability assessment is to quantify the reliability of structures under consideration of all uncertainties associated with the formulation of the failure criteria of the structure $[6,7]$. Reliability

* Corresponding author tel: +234- - 803 - 622 - 4407 
methods are used to estimate the probability of failure. The reliability, estimated as a measure of the safety of a structure, can be used in a decision (design) process.

The aim of this work is to carry out reliability-based evaluation of the structural performance of composite solid slender timber columns with Aluminium laminates using selected Nigerian timber species. It is based on the modification of the strength of solid timber columns with the introduction of Aluminium laminates. The strength variation of the timber is assessed to determine the strength behaviour of timber columns with varying Aluminium laminate thickness. The selected Nigerian timbers to be used in this study are Strombosia pustulata, Macrocarpa bequeriti, Nauclea diderrichii and Entandrophragma cylindricum which have local names of Itako, Oporoporo, Opepe and Ijebu respectively [8]. Reliability analyses of solid timber columns laminated with aluminium sheet of varying thickness were carried out. The reliability processes considered three failure modes which are bending, buckling and flexure. MATLAB [9] was used to run the First Order Reliability Method analyses incorporating programs that were designed for the three failure modes.

\section{LOAD MODELS ON A COMPOSITE COLUMN}

\subsection{Heterogeneous bars under direct stress (compression failure mode)}

For the composite timber-aluminium column that is subjected to compression stresses, the materials will be strained by equal amounts. The timber of cross sectional area, $A_{T}$, and young's modulus $E_{T}$, the resulting stress being $f_{T}$, and the aluminium having corresponding values of $A_{A}, E_{A}$ and $f_{A}$. If the composite column is under a load, $\mathrm{P}$, the initial strain, $\mathrm{x}$, is given as

$$
\begin{gathered}
x=\frac{f_{A}}{E_{A}} \\
x=\frac{f_{T}}{E_{T}}
\end{gathered}
$$

And the total load is given as

$$
P=A_{A} f_{A}+A_{T} f_{T}
$$

$A_{A} f_{A}$ and $A_{T} f_{T}$, being the loads carried by each of the constituent material.

Therefore,

$$
f_{A}=E_{A} x=\frac{E_{A}}{E_{T}} f_{T}
$$

$$
P=f_{T}\left(A_{T}+\frac{A_{A} E_{A}}{E_{T}}\right)
$$

Hence the stress in the timber section will be

$$
f_{T}=\frac{P}{A_{T}\left(1+\frac{A_{A} E_{A}}{A_{T} E_{T}}\right)}
$$

Conversely, the stress in the aluminium section will be

$$
f_{A}=\frac{P}{A_{A}\left(1+\frac{A_{T} E_{T}}{A_{A} E_{A}}\right)}
$$

And the total compressive stress acting on the column will be

$$
\frac{P}{A_{T}\left(1+\frac{A_{A} E_{A}}{A_{T} E_{T}}\right)}+\frac{P}{A_{A}\left(1+\frac{A_{T} E_{T}}{A_{A} E_{A}}\right)}
$$

From the performance function $\mathrm{G}(\mathrm{x})=\mathrm{R}-\mathrm{S}$,

$$
\begin{aligned}
G_{(x)}=\frac{k_{\text {mod }} f_{c, 0, k}+\alpha f_{c, 0, k}}{\gamma} & \\
& -Q_{K}\left(\gamma_{g} \alpha+\gamma_{q}\right)\left(\frac{1}{A_{T}\left(1+\frac{A_{A} E_{A}}{A_{T} E_{T}}\right)}\right. \\
& \left.+\frac{1}{A_{A}\left(1+\frac{A_{T} E_{T}}{A_{A} E_{A}}\right)}\right)
\end{aligned}
$$

Where $k_{\text {mod }}$ is the modification factor for duration of load and moisture content, $f_{c, 0, k}$ is characteristic compressive strength parallel to grain, $\alpha$ is load ratio, $\gamma_{g}$ and $\gamma_{q}$ are factors of safety for dead load and live load with values of 1.3 and 1.5 respectively

\subsection{Heterogeneous Bars Under Bending Stress (Bending Failure Mode)}

The composite timber-aluminium column would behave as one in resisting bending induced in it as a result of bending moments. The two materials are rigidly connected as shown in Figure 1 and thus the strains in the two materials are same due to bending stresses at a section.

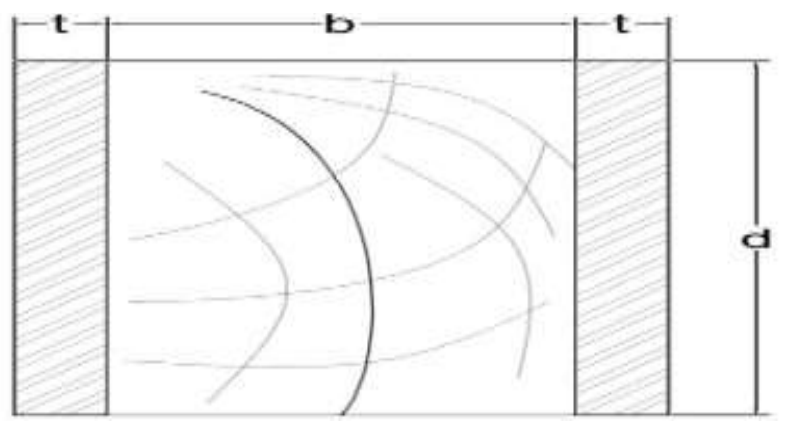

Figure1 Sectional Properties of Laminated Timber Column for Bending Failure Analysis

The aluminium gives a higher modulus of elasticity than the timber. For the composite timber-aluminium 
column that is subjected to bending stresses, the maximum stress in the composite section is given by

$$
\sigma_{\text {max }}=\frac{M y_{\text {composite }}}{I_{\text {composite }}}
$$

The total stress in the composite column based on individual stresses in each material

$$
\sigma_{\text {total }}=\sigma_{T}+\sigma_{A}
$$

Where; $\sigma_{T}=\frac{M y_{T}}{I_{T}}$ is stress in timber member and $\sigma_{A}=\frac{M y_{A}}{I_{A}}$ is the stress in the aluminium component.

Since there is an interaction between the two materials, the bending stresses will be distributed in the ratio of the flexural rigidity of both materials. In such case, the moment of inertia, I, of the two materials joined together is given by:

$$
I_{\text {composite }}=I_{\text {timber }}+I_{\text {aluminium }}
$$

Substituting into (10), the applied bending stress becomes

$$
\sigma=\frac{M y_{\text {composite }}}{I_{\text {timber }}+I_{\text {aluminium }}}
$$

And since timber and aluminium have different moduli of elasticity, the stresses in the compound column will be distributed based on the modulus as expressed below:

Bending stress in aluminium,

Bending stress in timber,

$$
\sigma=\frac{M y_{C} E_{A}}{E_{T} I_{T}+E_{A} I_{A}}
$$

$$
\sigma=\frac{M y_{C} E_{T}}{E_{T} I_{T}+E_{A} I_{A}}
$$

Hence, the total applied bending stress on the composite column is given as:

$$
R=\frac{M y_{C}}{E_{T} I_{T}+E_{A} I_{A}}\left(E_{A}+E_{T}\right)
$$

The applied moment on the composite column is given by:

$$
\mathrm{M}_{\text {applied }}=\frac{P L^{2}}{8}
$$

Where $\mathrm{L}$ is the column length and $\mathrm{P}$ is applied load given as $q_{k}(1.35 \alpha+1.5)$ where $q_{k}$ is live load and $\alpha$ is dead to live load ratio, $M$ is the moment acting on the column due to lateral loads (beam-column), $y$ is the distance from the centroidal axis.

From the performance function $\mathrm{G}(\mathrm{x})=\mathrm{R}-\mathrm{S}$,

$$
\begin{aligned}
& G_{(x)}=\left(\frac{M y_{C}}{E_{T} I_{T}+E_{A} I_{A}}\left(E_{A}+E_{T}\right)\right) \\
&-0.125 Q_{K}(1.35 \alpha+1.5) L^{2}
\end{aligned}
$$

\subsection{Flexure Buckling Failure Mode}

There is the tendency for the column to buckle in bending due to axial load subjected on it. [10] gives the flexural buckling of timber to satisfy the interactive formula in the following equation,

$$
\left(\frac{\sigma_{m, d}}{k_{c r i t} f_{m, d}}\right)^{2}+\frac{\sigma_{c, 0, d}}{k_{c, z} f_{c, 0, d}} \leq 1
$$

From the performance function $\mathrm{G}(\mathrm{x})=\mathrm{R}-\mathrm{S}$,

$$
G_{(X)}=1-\left(\left(\frac{\sigma_{m, d}}{k_{c r i t} f_{m, d}}\right)^{2}+\frac{\sigma_{c, 0, d}}{k_{c, z} f_{c, 0, d}}\right)
$$

Where: $\sigma_{m, d}$ is the bending stress, $\sigma_{c, 0, d}$ is the design compressive stress parallel to grain, $f_{m, d}$ is the bending strength parallel to grain, $f_{c, 0, d}$ is the design compressive strength parallel to grain.

$\mathrm{K}_{\mathrm{c}, \mathrm{z}}$ is the column instability factor given as:

$$
k_{c, z}=\frac{1}{k_{z}+\sqrt{k^{2}{ }_{z}-\lambda^{2}{ }_{r e l, z}}}
$$

Where: $k_{z}=0.5\left(1+\beta_{c}\left(\lambda_{\text {rel, }, z}-0.3\right)+\lambda^{2}{ }_{r e l, z}\right)$ and $\beta_{c}$ is a factor for members within a define limit and is 0.2 for solid timber.

The relative slenderness ratio $\lambda_{\text {rel,z }}=\frac{\lambda_{z}}{\pi} \sqrt{\frac{f_{c, 0, k}}{E_{0.05}}}$ $\lambda_{z}$ is the slenderness ratio in the $z$-axis

\section{THE LIMIT STATE PRINCIPLE}

The performance of an engineering structure depends on the type and magnitude of the applied load and the structural strength and stiffness [6]. It is convenient to describe failure events in terms of functional relations, which if they are fulfilled, define that the failure event $\mathbf{F}$ will occur:

$$
f=\{g(x) \leq 0\}
$$

where $g(x)$ is a limit state function, the components of the vector $x$ are basic random variables $X$ representing all relevant uncertainties influencing the problem at hand. The failure event $\mathbf{F}$ is defined as the set of realisations of the limit state function $g(x)$, which are zero or negative.

The First Order Reliability Method (FORM) is a level II (reliability index method) analysis for solving probability of failure where uncertain parameters are modelled by the mean values and the standard deviations, and by the correlation coefficients between stochastic variables $[5,11]$. FORM involves the use of stochastic variables and models, where the stochastic variables are denoted $X=\left(X_{1}, \ldots, X_{n}\right)$. The $\mathrm{n}$ stochastic variables could model physical uncertainty, model uncertainty or statistical uncertainties.

The application of FORM gives the state of the structure; whether the structure is in a safe state or in a failure state. The basic variable space is divided, 
by the failure state (limit state surface), into two sets: the safe and the failure set.

The failure surface is expressed by the equation:

$$
g(x)=g\left(x_{1}, \ldots, x_{n}\right)=0
$$

Where $g(x)$ is the failure function

If $\mathrm{R}$ is the resistance and $\mathrm{S}$ the effect of actions, the performance function $\mathrm{g}$ is given as [12][13]:

$$
g=R-S
$$

$\mathrm{R}, \mathrm{S}$ and $\mathrm{g}$ are random variables.

If the performance function, $g$, is normally distributed, the expected value $\mu_{g}$ and standard deviation $\sigma_{g}$ can be expressed as:

$$
\beta=\frac{\mu_{g}}{\sigma_{g}}
$$

$\beta$ is the Hasofer \& Lind reliability index and it is defined as the smallest distance from the origin $O$ in the $u$-space to the failure surface $g(x)=0$.

And

$$
\begin{aligned}
P_{f}=P(g(x) \leq 0) & =P\left(\mu_{g}-\beta \sigma_{g} \leq 0\right)=P\left(\mathrm{U} \leq-\frac{\mu_{g}}{\sigma_{g}}\right) \\
= & \Phi(-\beta)
\end{aligned}
$$

$\Phi$ is the standard normal distribution function and $U$ is a standard normally distributed variable with expected value zero and unit standard deviation $\left(\mu_{g}=0, \sigma_{g}=1\right)$.

For a linear failure function, $M$, if the stochastic variables $\mathrm{P}$ and $\mathrm{S}$ are independent, then the index becomes:

$$
\beta=\frac{\mu_{R}-\mu_{S}}{\sigma_{R}-\sigma_{S}}
$$

For other distributions of $\mathrm{g}, \beta$ is only a conventional measure of the reliability $P_{s}=\left(1-P_{f}\right)$.

\section{METHODS}

The assumed cross sections replicate usual conditions and dead loads are established according to [14]. The modification factor takes into account the duration of load effect and moisture content and its value is considered as constant and equal to $\mathrm{k}_{\bmod }=$ 0.60 , as described in [10]. The reliability-based analyses were carried out with a computer program written in MATLAB. The computer program performs the reliability analysis of axially loaded solid slender columns. Three failure modes were considered as follows: compression criterion (failure mode I), bending criterion (failure mode II) and flexuralbuckling (failure mode III).

\subsection{Limit State Structural Design Parameters}

The column used in the reliability analysis is considered as an axially loaded solid rectangular column with varying aluminium laminates at the weaker axis of buckling.

i. For the load model, the factors of safety are given as: $\gamma_{q}=1.5$ for imposed load and $\gamma_{g}=1.35$ for dead load

ii. The timber column is considered a structural member in a dwelling and it is considered as permanent structure. Hence, the strength modification, $\mathrm{k}_{\text {mod }}$ is 0.6 [10].

iii. The properties of timber that were obtained from [15] were used for the basic variables whereas the statistical parameters and

\begin{tabular}{|c|c|c|c|c|c|c|}
\hline S/no & Variables & Meaning & Distribution & Mean & Covariance & SD \\
\hline 1 & $\overline{\mathrm{f}_{\mathrm{c}, 0 \mathrm{k}(\mathrm{k}}(\text { itako) }}$ & & lognormal & $29.58 \mathrm{~N} / \mathrm{mm}^{2}$ & 0.13 & 3.84 \\
\hline 2 & $\mathrm{f}_{\mathrm{c}, 0, \mathrm{k}}$ (Oporoporo) & Characteristic & lognormal & $20.82 \mathrm{~N} / \mathrm{mm}^{2}$ & 0.13 & 2.71 \\
\hline 3 & $\mathrm{f}_{\mathrm{c}, 0, \mathrm{k}}$ (opepe) & compressive strength & lognormal & $27.18 \mathrm{~N} / \mathrm{mm}^{2}$ & 0.13 & 3.53 \\
\hline 4 & $\mathrm{f}_{\mathrm{c}, 0, \mathrm{k}}(\mathrm{ijebu})$ & parallel to grain & lognormal & $24.16 \mathrm{~N} / \mathrm{mm}^{2}$ & 0.13 & 3.14 \\
\hline 5 & $\mathrm{f}_{\mathrm{c}, 0, \mathrm{k}}$ (aluminium) & & lognormal & $100 \mathrm{~N} / \mathrm{mm}^{2}$ & 0.13 & 13 \\
\hline 6 & Qk & Imposed load & Gumbel & $15 \mathrm{kN}$ & 0.32 & 4.8 \\
\hline 7 & $B$ & Width of column & Normal & $300 \mathrm{~mm}$ & 0.47 & 141 \\
\hline 8 & $\mathrm{H}$ & Thickness of column & Normal & $100 \mathrm{~mm}$ & 0.47 & 47 \\
\hline 9 & Eitako & & Lognormal & $9.18 \mathrm{kN} / \mathrm{mm}^{2}$ & 0.21 & 1.93 \\
\hline 10 & EOporoporo & & lognormal & $4.95 \mathrm{kN} / \mathrm{mm}^{2}$ & 0.21 & 1.04 \\
\hline 11 & Eopepe & Modulus of elasticity & Lognormal & $8.42 \mathrm{kN} / \mathrm{mm}^{2}$ & 0.21 & 1.77 \\
\hline 12 & $\mathrm{E}_{\mathrm{ijebu}}$ & & Lognormal & $7.36 \mathrm{kN} / \mathrm{mm}^{2}$ & 0.21 & 1.55 \\
\hline 13 & Ealuminium & & lognormal & $70 \mathrm{kN} / \mathrm{mm}^{2}$ & 0.21 & 14.7 \\
\hline
\end{tabular}
distribution models were obtained from [16]

\subsection{Stochastic Models for the Basic Variables} The values of data used in the models are presented in Tables 1, 2 and 3.

Table 1: Stochastic Parameters for Compression Failure Mode 
Table 2: Stochastic Parameters for Bending Failure Mode

\begin{tabular}{|c|c|c|c|c|c|c|}
\hline S/no & Variables & Meaning & Distribution & Mean & Covariance & SD \\
\hline 1 & $\mathrm{f}_{\mathrm{c}, 90, \mathrm{k}}($ itako) & & Lognormal & $51.97 \mathrm{~N} / \mathrm{mm}^{2}$ & 0.13 & 6.76 \\
\hline 2 & $\mathrm{f}_{\mathrm{c}, 90, \mathrm{k}}($ Oporoporo $)$ & Unaracteristlc & Lognormal & $32.30 \mathrm{~N} / \mathrm{mm}^{2}$ & 0.13 & 4.2 \\
\hline 3 & $f_{c, 90, k}($ opepe $)$ & Denaing strengin & Lognormal & $23.80 \mathrm{~N} / \mathrm{mm}^{2}$ & 0.13 & 3.1 \\
\hline 4 & $\mathrm{f}_{\mathrm{c}, 90, \mathrm{k}(\mathrm{ijebu})}$ & perpendicular to & Lognormal & $33.12 \mathrm{~N} / \mathrm{mm}^{2}$ & 0.13 & 4.3 \\
\hline 5 & $\mathrm{f}_{\mathrm{c}, 90, \mathrm{k}}($ aluminium $)$ & & Lognormal & $100 \mathrm{~N} / \mathrm{mm}^{2}$ & 0.13 & 13 \\
\hline 6 & Qk & Imposed load & Gumbel & $15 \mathrm{kN}$ & 0.32 & 4.8 \\
\hline 7 & $B$ & Width of column & Normal & $300 \mathrm{~mm}$ & 0.47 & 141 \\
\hline 8 & $\mathrm{H}$ & Thickness of column & Normal & $100 \mathrm{~mm}$ & 0.47 & 47 \\
\hline 9 & $\mathrm{~L}$ & Column height & Normal & $3500 \mathrm{~mm}$ & 0.28 & 980 \\
\hline 10 & Eitako & & Lognormal & $10.0 \mathrm{kN} / \mathrm{mm}^{2}$ & 0.21 & 1.93 \\
\hline 11 & EOporoporo & & Lognormal & $6.67 \mathrm{kN} / \mathrm{mm}^{2}$ & 0.21 & 1.04 \\
\hline 12 & $E_{\text {opepe }}$ & Modulus of elasticity & Lognormal & $9.28 \mathrm{kN} / \mathrm{mm}^{2}$ & 0.21 & 1.77 \\
\hline 13 & $E_{\mathrm{ijebu}}$ & & Lognormal & $8.50 \mathrm{kN} / \mathrm{mm}^{2}$ & 0.21 & 1.55 \\
\hline 14 & Ealuminium & & lognormal & $70 \mathrm{kN} / \mathrm{mm}^{2}$ & 0.21 & 14.7 \\
\hline
\end{tabular}

Table 3 : Stochastic Parameters for Flexural Failure Mode

\begin{tabular}{|c|c|c|c|c|c|c|}
\hline S/no & Variables & Meaning & Distribution & Mean & Covariance & SD \\
\hline 1 & $\mathrm{f}_{\mathrm{c}, 0, \mathrm{k}(\text { itako) }}$ & \multirow{5}{*}{$\begin{array}{l}\text { Characteristic } \\
\text { compressive strength } \\
\text { parallel to grain }\end{array}$} & lognormal & $29.58 \mathrm{~N} / \mathrm{mm}^{2}$ & 0.13 & 3.84 \\
\hline 2 & $\mathrm{f}_{\mathrm{c}, 0, \mathrm{k}}($ Oporoporo) & & lognormal & $20.82 \mathrm{~N} / \mathrm{mm}^{2}$ & 0.13 & 2.71 \\
\hline 3 & $\mathrm{f}_{\mathrm{c}, 0, \mathrm{k}}($ opepe $)$ & & lognormal & $27.18 \mathrm{~N} / \mathrm{mm}^{2}$ & 0.13 & 3.53 \\
\hline 4 & $f_{c, 0, k}(i j e b u)$ & & lognormal & $24.16 \mathrm{~N} / \mathrm{mm}^{2}$ & 0.13 & 3.14 \\
\hline 5 & $\mathrm{f}_{\mathrm{c}, 0, \mathrm{k}}($ aluminium $)$ & & lognormal & $100 \mathrm{~N} / \mathrm{mm}^{2}$ & 0.13 & 13 \\
\hline 6 & $\mathrm{f}_{\mathrm{c}, 90, \mathrm{k}}($ itako) & \multirow{5}{*}{$\begin{array}{l}\text { Characteristic } \\
\text { compressive strength } \\
\text { perpendicular to grain }\end{array}$} & Lognormal & $51.97 \mathrm{~N} / \mathrm{mm}^{2}$ & 0.13 & 6.76 \\
\hline 7 & $\mathrm{f}_{\mathrm{c}, 90, \mathrm{k}}($ Oporoporo) & & Lognormal & $32.30 \mathrm{~N} / \mathrm{mm}^{2}$ & 0.13 & 4.2 \\
\hline 8 & $\mathrm{f}_{\mathrm{c}, 90, \mathrm{k}(\text { opepe })}$ & & Lognormal & $23.80 \mathrm{~N} / \mathrm{mm}^{2}$ & 0.13 & 3.1 \\
\hline 9 & $\mathrm{f}_{\mathrm{c}, 90, \mathrm{k}(\mathrm{ijebu})}$ & & Lognormal & $33.12 \mathrm{~N} / \mathrm{mm}^{2}$ & 0.13 & 4.3 \\
\hline 10 & $\mathrm{f}_{\mathrm{c}, 90, \mathrm{k}}($ aluminium $)$ & & Lognormal & $100 \mathrm{~N} / \mathrm{mm}^{2}$ & 0.13 & 13 \\
\hline 11 & Qk & Imposed load & Gumbel & $15 \mathrm{kN}$ & 0.32 & 4.8 \\
\hline 12 & B & Width of column & Normal & $300 \mathrm{~mm}$ & 0.47 & 141 \\
\hline 13 & $\mathrm{H}$ & Thickness of column & Normal & $100 \mathrm{~mm}$ & 0.47 & 47 \\
\hline 14 & $\mathrm{~L}$ & Column height & Normal & $3500 \mathrm{~mm}$ & 0.28 & 980 \\
\hline 15 & Eitako & \multirow{5}{*}{ Modulus of elasticity } & Lognormal & $10.0 \mathrm{kN} / \mathrm{mm}^{2}$ & 0.21 & 1.93 \\
\hline 16 & Eoporoporo & & Lognormal & $6.67 \mathrm{kN} / \mathrm{mm}^{2}$ & 0.21 & 1.04 \\
\hline 17 & Eopepe & & Lognormal & $9.28 \mathrm{kN} / \mathrm{mm}^{2}$ & 0.21 & 1.77 \\
\hline 18 & $E_{\text {ijebu }}$ & & Lognormal & $8.50 \mathrm{kN} / \mathrm{mm}^{2}$ & 0.21 & 1.55 \\
\hline 19 & Ealuminium & & lognormal & $70 \mathrm{kN} / \mathrm{mm}^{2}$ & 0.21 & 14.7 \\
\hline
\end{tabular}

\section{DISCUSSION OF RESULTS}

The results for the reliability analysis are presented in Figures 3 to 12 and all results show a general improvement in the safety (reliability) indices of the column with increase in laminate thickness but a decline in safety indices with increase in load ratios. The performance of the structure shows varied safety indices for the three modes of failure and for the design parameters that were inputted into the limit state functions.

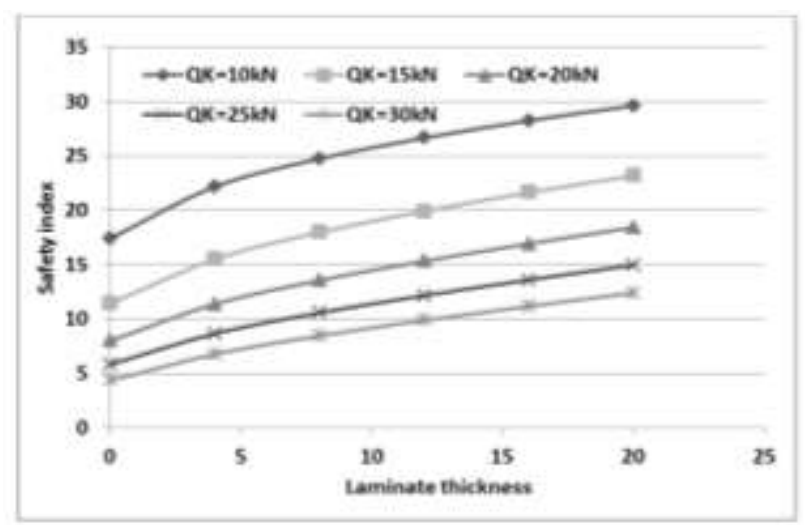

Figure 3: Safety Index Versus Laminate Thickness at Various imposed Loads for Strombosia Pustulata 


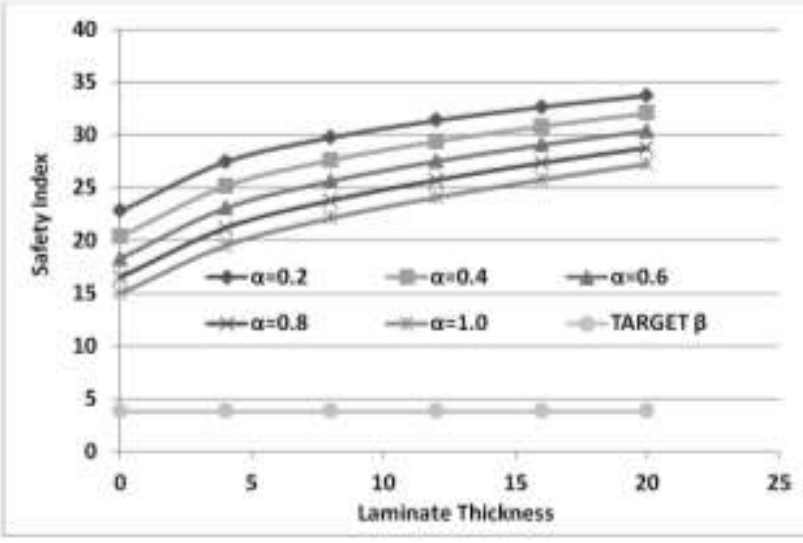

Figure 4: Safety Index versus Laminate Thickness at Various Load Ratios for Strombosia Pustulata

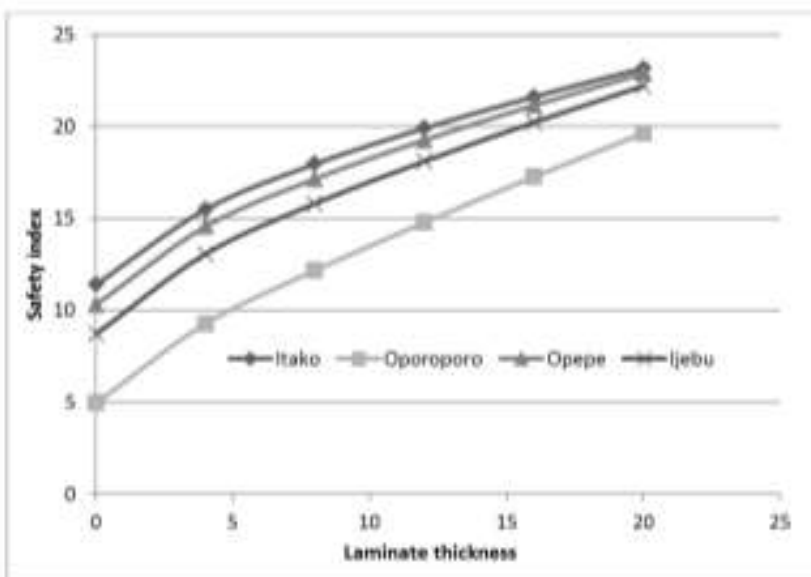

Figure 5: Safety Index versus Laminate Thickness for Test Species at Design Parameters

\subsubsection{Results for Compression Mode of Failure}

The results for the compression mode of failure show that the column is very safe in compression with all varied parameters having safety indices well above the target safety index of 3.8. Figure 3 shows the effects of varying the imposed loads on the safety index of the column. Figure 4 shows the effect of varying dead-to-live load ratios on the safety index of the column with lowest safety indices of 14.96, highest $\beta$ of 22.77 without laminate and minimum safety indices of 27.26 and highest $\beta$ of 33.73 for the timber column with $20 \mathrm{~mm}$ thick aluminium laminate. It can be observed that the disparity between the safety indices for load ratios is not as large as that of varying the imposed load. Figure 5 shows the effects of the inherent strength of the timber species on the safety indices of the column using the all the standard design parameters. It will be observed that varying the imposed loads has a greater effect on the safety index with a change in $\beta$ from 4.3 to 17.4 for the timber column without laminates and from 12.4 to 29.6 for the column with laminate thickness of
$20 \mathrm{~mm}$. The effect of the timber compressive strength is also evident in Figure 5 with the big disparity in the safety indices for the four timber species. It can be observed that itako timber specie gave a large safety index of 11.4 without laminate and 23.2 with laminate of $20 \mathrm{~mm}$ thickness.

\subsubsection{Results for Bending Mode of Failure}

The results of the safety indices for the bending criterion of failure for the laminated timber column is shown in Figures 6 to 9 with the varied parameters being imposed load, load ratios, column height and timber bending strength.

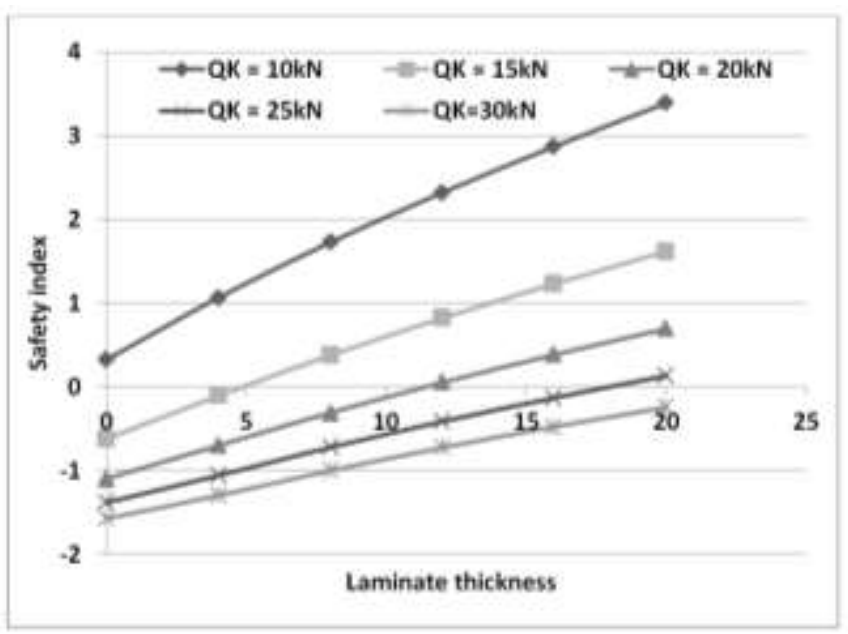

Figure 6: Safety Index versus Laminate Thickness at Various Loads for Strombosia Pustulata

Figure 6 shows the effects of load variation on the safety of timber columns in bending. It can be observed that the timber column will fail for all imposed loads except for $10 \mathrm{kN}$ applied load where the safety index is 0.32 for column without laminate and 3.38 for laminate with thickness of $20 \mathrm{~mm}$. Also, the laminate thickness of $10 \mathrm{~mm}$, gives a safe column for imposed load of $15 \mathrm{kN}$ and $20 \mathrm{kN}$. Figure 7 gives the effect of varying dead-to-live load ratio on the safety of the column under bending loads. It can be observed that the column is in safe zone for all load ratios and exceeds the target safety index for load ratios of 0.2 and 0.4 for laminate thickness of $12 \mathrm{~mm}$ and $16 \mathrm{~mm}$ respectively. Figure 8 shows the effect the height of column will have on the safety of the column. The column with height of $1 \mathrm{~m}$ is very safe with safety index of 3.8 without laminate, from where it increases to a safety index of 9.01 for a laminate of $20 \mathrm{~mm}$ thickness. Most of the column heights are safe except for $3 \mathrm{~m}$ and $3.5 \mathrm{~m}$ where it is 
safe only from the point of application of laminate of $5 \mathrm{~mm}$ thickness.

It is also observed in Figure8 that the change in length gave the most critical state in the change of the safety indices of the column while variations in load ratios have the least impact on the column safety index. As such the design of the column should be more centred on the column height than other parameters in bending failure mode.

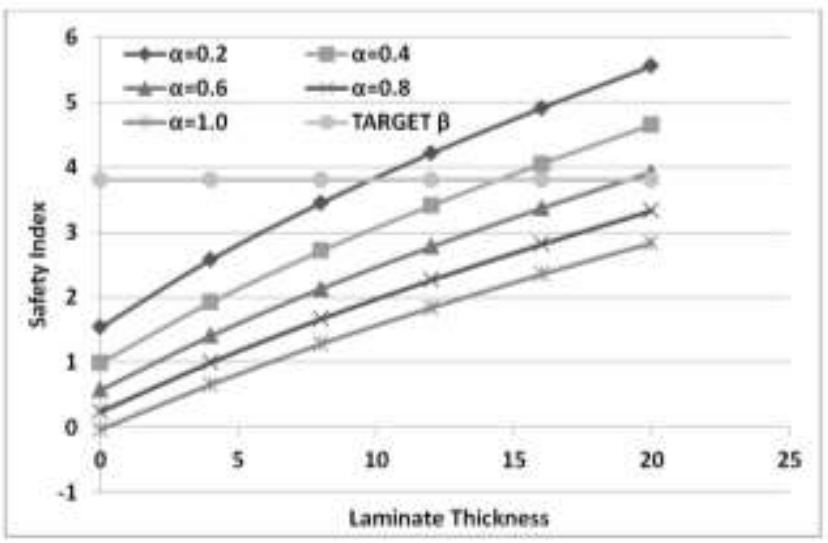

Figure 7: Safety Index versus Laminate Thickness at Various Load Ratios for Strombosia Pustulata

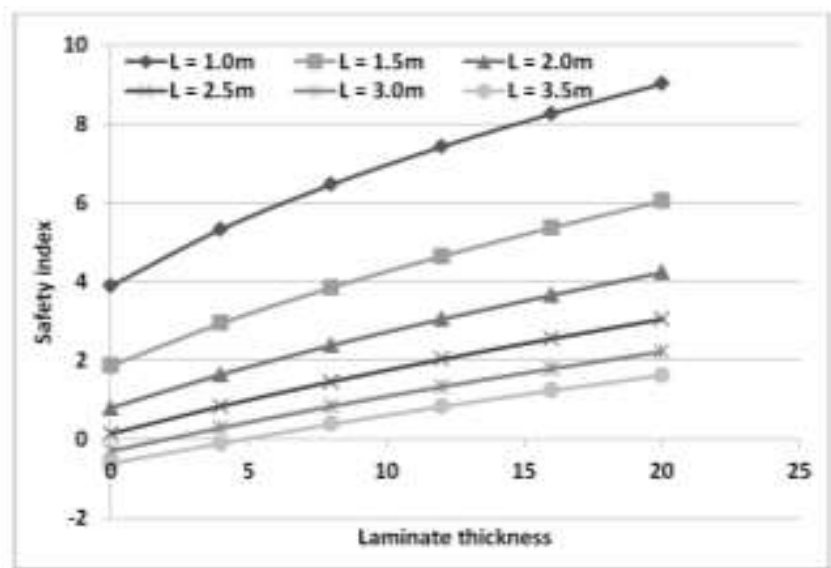

Figure 8: Safety Index versus Laminate Thickness at Various Column Heights for Strombosia Pustulata

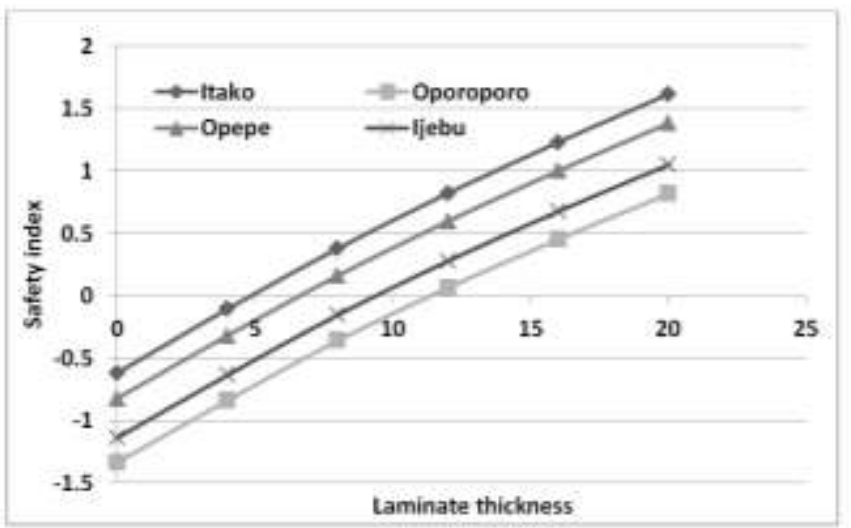

Figure 9: Safety Index versus Laminate Thickness for Timber Species Using Standard Design Parameters
Figure 9 shows the comparison of safety indices for the four timber species under the same standard design parameter of column height, load and geometric section. It can be observed that itako is safest of the four timber species. Also, a laminate thickness of $12 \mathrm{~mm}$ is needed to bring the column to a safe zone.

\subsubsection{Results for flexural buckling mode of failure}

Figures 10 to 12 show the safety indices of the timber column for the flexural buckling mode of failure of columns. The charts show that varying loads and column height are the critical parameters that affect the safety indices of the column in this mode of failure.

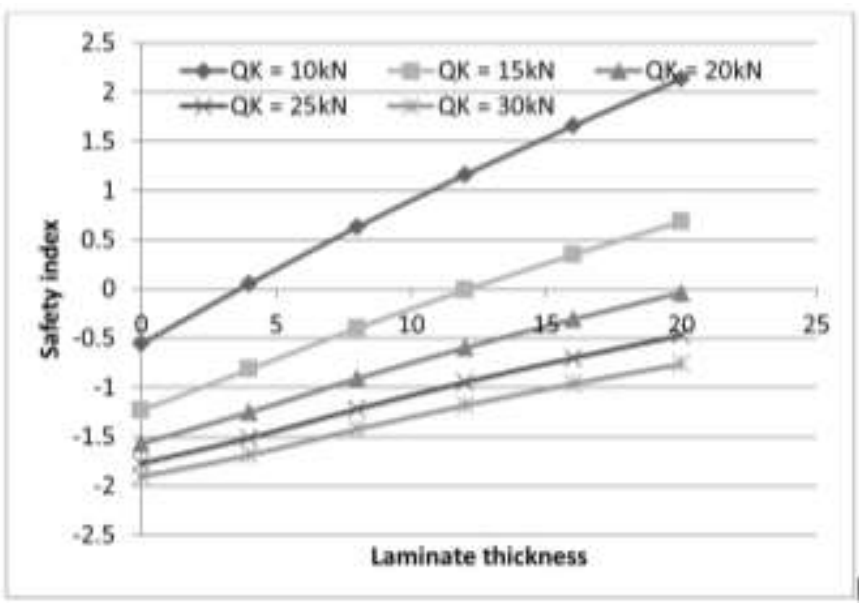

Figure 10: Safety Index versus Laminate Thickness at Various Loads for Strombosia Pustulata

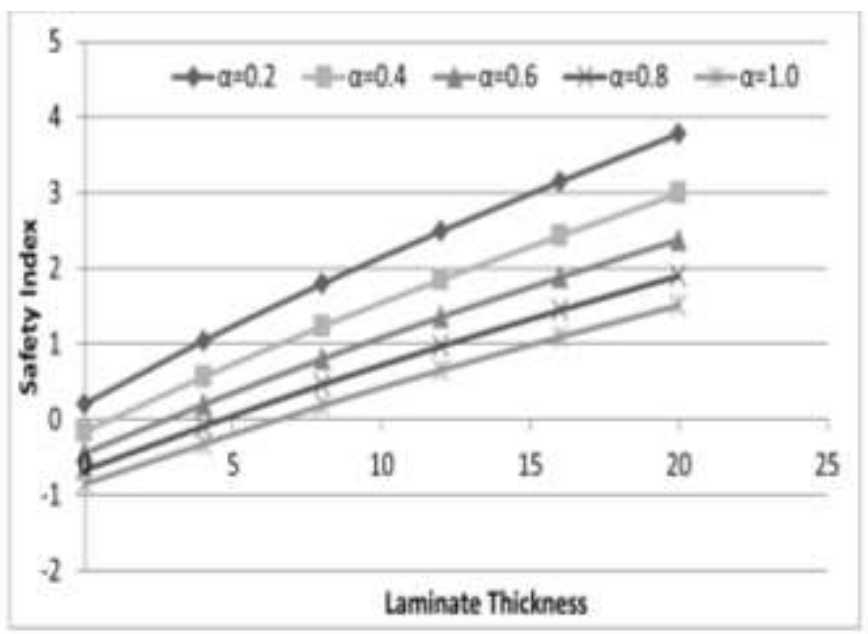

Figure 11: Safety Index versus Laminate Thickness at various Load Ratios for Strombosia Pustulata 


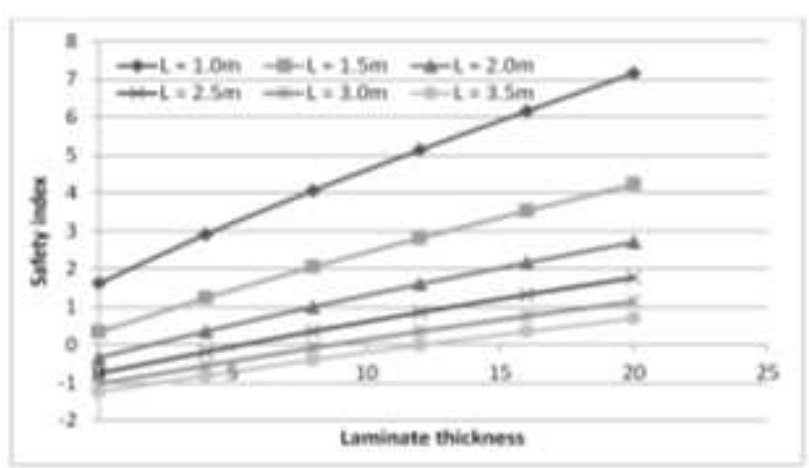

Figure 12: Safety Index versus Laminate Thickness with Varied Column Height

Figure 10 shows the result of varying imposed loads on the safety of the laminate timber columns. It will be observed that the column fails for imposed loads of $20 \mathrm{kN}, 25 \mathrm{kN}$ and $30 \mathrm{kN}$ at all laminate thickness. The column is safe for $15 \mathrm{kN}$ when the laminate of $12 \mathrm{~mm}$ thickness is used and is safe for all values of $10 \mathrm{kN}$ with the highest safety index being 2.14 for laminate of $20 \mathrm{~mm}$ thickness. Figure 11 shows the result of dead-to-live load ratios on the safety of the composite column where the column is safe when a laminate thickness of $10 \mathrm{~mm}$ is used for the column in the case of load ratio of 1.0 and $4 \mathrm{~mm}$ for load ratios of 0.6 and 0.8 while all other load ratios gave a safe design. Figure 12 shows the safety index based on the height of column for flexural buckling. The result shows that that the column is safe for heights of $1 \mathrm{~m}$ and $1.5 \mathrm{~m}$, but for greater heights, the laminate thickness of $12 \mathrm{~mm}$ is used to ensure safety. Also, the column height of $1 \mathrm{~m}$ should be used with $8 \mathrm{~mm}$ thick laminate and $16 \mathrm{~mm}$ thick laminates for $1.5 \mathrm{~mm}$ column height to ensure it meets up with the target reliability index of 3.8 as stipulated in [11] and [12].

\section{CONCLUSION}

Reliability analyses of a laminated timber column with varying aluminium laminate thickness were carried out. The effects of varying loads, timber strengths (compressive and bending) and column height on the safety indices were considered with varying thickness of aluminium laminate. The results of the study show that for a timber column, the effect of change in imposed loads had a great effect on the safety indices of columns for both compression and bending but more critical in bending. Also the effect of load is more profound on the safety index of columns in bending while the effect of change in load ratio showed little effect on the overall change of safety index. It is observed in the charts that the aluminium laminate greatly increased the strength of the column and hence gave a favourable increase in the safety indices for all the failure criteria.

\section{REFERENCES}

[1] Porteous J. ans Kermani, A. Structural Timber Design to Eurocodes. Blackwell Publishing, USA, 2007.

[2] Mazzolani, F. M. "Design of Aluminium Structures according to EC 9", Proceedings of the Nordic Steel Construction Conference 98, Bergen, Norway, 1998.

[3] Mazzolani, F. M. Aluminium Structural Design, CISM 2003, Springer- Verlag, Wien, New York, 2003.

[4] BS EN 1999-1-1. Eurocode 9: Design of aluminium structures - Part 1-1: General structural rules, 2007.

[5] Sørensen J. D. "Structural Reliability, Structural Reliability theory and risk Analysis", https://d1rkab7tlay5f1.cloudfront.net/TBM/Over\%20 faculteit/Afdelingen/Values\%2C\%20Technology\%20 and\%20Innovation/People/Full\%20Professors/Pieter \%20van\%20Gelder/Citations/citatie215.pdf, Accessed March 10, 2016.

[6] Köhler, J., Sørensen, J. D., Faber, H. M. "Probabilistic modelling of timber structures", Journal of Structural Safety, vol. 29, issue 4, pp. 255-267, 2007.

[7] Melchers R. E. Structural Reliability Analysis and Prediction. Second Edition. John Wiley, Chichester, 1999.

[8] NCP 2. The Use of Timber for Construction. Nigerian Standard Code of Practice, Nigerian Standard Organisation, Federal Ministry of Industries, Lagos, Nigeria, 1973.

[9] MATLAB. MATLAB version 7.13.0.564 Release 2011b for Windows, The MATHWORKS, 2007

[9] BS EN 1995. Eurocode 5: Part 1-1: Design of Timber Structures. General -Common Rules for Buildings. CSI, Prague, 2004.

[10] JCSS 2006. "Joint Committee on Structural SafetyProbabilistic Model Code". http://www.jcss.ethz.ch, Accessed on July 2016

[11] BS EN 1990. Eurocode 0-Basis of structural design. British standards. CEN Brussels, 2002.

[12] Ditlevsen O. and Madsen H. O. Structural Reliability Methods. John Wiley \& Sons, Chichester, 2005

[13] BS EN 1991-1-1. Eurocode 1: Actions on structures Part 1-1: General actions - Densities, self-weight, imposed loads for buildings, 2002.

[14] Abubakar I., Nabade A. M. "Physical and Mechanical Properties of Some Common Nigerian Timber Species Based on Limit State Design Approach". Study of Civil Engineering and Architecture (SCEA) Volume 2 Issue 4, December, 2013.

[15] Benu M. J., Sule S. and Nwofor T. C. Reliability Analysis of a Square Solid Timber Column, Pelagia Research Library, Advances in Applied Science Research, 3 (4), 2012, pp 1997-2004. 